\title{
The impact of Agenda 2000's structural policy reform on FDI in the EU
}

\author{
Fritz Breuss $^{\mathrm{a}, \mathrm{b}, *}$, Peter Egger ${ }^{\mathrm{c}}$, Michael Pfaffermayr ${ }^{\mathrm{c}}$

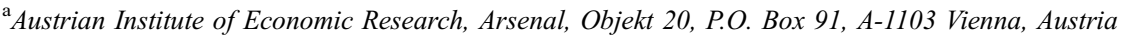 \\ ${ }^{\mathrm{b}}$ Research Institute for European Affairs at the Vienna University of Economics and Business \\ Administration, Vienna, Austria \\ ${ }^{\mathrm{c}}$ Department of Economic Theory, Economic Policy and Economic History at the University of \\ Innsbruck, Innsbruck, Austria
}

Received 1 October 2000; accepted 1 June 2001

\begin{abstract}
This paper analyses the effects of Agenda 2000's policy reform on the stocks of outward FDI to the European Union member countries. In a three-factors proximityconcentration New Trade Theory model we identify the channels of influence on the FDI decision. In the empirical part, we estimate a dynamic panel data model and find that structural expenditures exert a significant positive impact on real stocks of outward FDI to EU countries. We simulate the Agenda 2000 program and obtain short-term and long-term effects of the EU country-specific changes in structural budgets on FDI to these countries. (C) 2001 Society for Policy Modeling. Published by Elsevier Science Inc.
\end{abstract}

JEL classification: C33; F14; F15

Keywords: FDI; Gravity equation; European integration; Panel econometrics

* Corresponding author. Austrian Institute of Economic Research, Arsenal, Objekt 20, P.O. Box 91, A-1103 Vienna, Austria. Tel.: +43-1-798-2601-220.

E-mail addresses: fritz.breuss@wifo.ac.at (F. Breuss), peter.egger@uibk.ac.at (P. Egger), michael.pfaffermayr@uibk.ac.at (M. Pfaffermayr). 


\section{Introduction}

For more than a decade the European Union used Structural and Cohesion Funds to promote convergence among regions within the Union. According to the Agenda 2000 these funds also play an important role in closing the gap in infrastructure facilities, capital endowments, and more generally, in welfare between the new entrants and the current members in the process of Eastern Enlargement. However, to avoid exaggerated financial pressure on the current net payers and "to maintain the present average aid intensity levels," the new Structural Operations in the Central and Eastern economies will be financed by redistributing structural expenditures from current to future members, "thereby consolidating the present overall effort in this field" (Presidency Conclusions, Berlin European Council, 24 and 25 March 1999, §28).

In particular, Agenda 2000 relates to the following priority areas: (a) continuation of the agricultural reform (McSharry reform); (b) increasing the effectiveness of the Structural and the Cohesion Funds by greater concentration of projects on specific objectives and geographical areas and reducing the number of objectives from seven to three; (c) strengthening the preaccession strategy for applicant countries by setting up two financial mechanisms: a preaccession structural instrument (ISPA) to support improved transport and environmental protection infrastructures and a preaccession agricultural instrument (SAPARD) to facilitate the long-term adjustment of agriculture and rural areas of the applicant countries; and (d) adopting a new financial framework for the period 2000-2006 in order to enable the Union to meet the main challenges of the beginning of the 21 st century, in particular enlargement in this period by maximum six new countries, while ensuring budgetary discipline.

At the Berlin European Council, the heads of government or states decided that financing EU enlargement must be realized without changing the own resources ceiling of $1.27 \%$ of GNP between 2000 and 2006. The additional costs of enlargement in the range of around 80 billion euros (at 1999 prices) in the mentioned period or $0.25 \%$ of EU GDP in 2006 for six new members must be financed by reducing the transfers to the present EU members - mainly in the area of structural operations. The Interinstitutional Agreement between the European Parliament, the Council, and the Commission (May 6, 1999; OJ No. C172/1, June 18, 1999) on budget discipline maintains the funding for economic and social cohesion at $0.46 \%$ of the Union's GNP for the period 2000-2006 (as was already the case in the period 1993-1999). However, as this ceiling covers 21 EU countries, then the EU-15 countries will get relatively less than in the former program period.

Due to the lack of experience in the CEEC it is difficult to figure out how this switch in the system of transfers will affect the membership aspirants. However, it is possible to analyze the effects of structural expenditures in the past on the present EU members. We concentrate on the effects of structural and cohesion expenditures on FDI stocks in the EU countries. Using a New Trade Theory model, which also accounts for the activity of multinational enterprises (MNEs), we argue that the 
trade-off between the proximity to the market (i.e., going multinational) and the concentration of production facilities (i.e., exporting) may be affected by structural expenditures. These may decrease the transport cost and/or a plant setup cost of MNEs. Which effect dominates depends on the subsidized investments in the respective countries. From a sending country's perspective, one should observe a higher FDI activity to countries where the structural expenditures are directed relatively stronger to plant setup cost reducing subsidies.

For the empirical analysis of the impact of structural and cohesion funds on FDI we estimate a gravity model ${ }^{1}$ of bilateral stocks of outward FDI of OECD countries in the EU economies. We find that the structural funds indeed exert a significant positive impact on outward stocks of FDI. Using the estimated parameters, we are able to simulate the consequences of the reduction in structural funds as envisaged by the Berlin European Council for the current EU members as recipients of FDI. We find that the annual decreases in structural funds for the period 2000-2006 relative to the period 1995-1999 affect some of the EU countries strongly (especially Ireland, Denmark, Belgium and Luxembourg, and the UK), resulting in reductions of real stocks of FDI between $15.9 \%$ and $6.6 \%$. Of course, this is not the only effect. We should also expect a compensating increase in demand for current EU members' goods and services by the increasing structural expenditures in the CEEC. Given the distribution effects within the current EU countries, one should also seek for compensating measures, which facilitate FDI in and upgrade the location advantage of the current EU member states.

The paper proceeds as follows. In Section 2 we briefly present the theoretical model, Section 3 sets out the empirical framework. Section 4 contains the estimation results and evaluates the corresponding short-run and long-run impact on real FDI stocks in the EU. Section 5 concludes.

\section{Theoretical background}

In order to analyze the impact of structural funds on FDI, we present a model where a single horizontally differentiated good is produced by national enterprises (NE) and by horizontally organized MNE. In contrast to Markusen and Venables $(1998,2000)$, we base the theoretical setup on a three-factors model and introduce structural subsidies as a determinant of both trade costs and plant setup costs at a possibly different intensity. On the one hand, structural payments can be used to improve infrastructure facilities like railway or highway networks, thereby reducing trade costs. On the other hand, they can be used to directly subsidize investments (both from abroad and from within a country) in specific regions or for specific objectives.

\footnotetext{
${ }^{1}$ Compare Bergstrand (1989, 1990), Helpman (1987), Helpman \& Krugman (1985) and Wang \& Winters (1991).
} 
Both location and the scope of activity of firms are endogenously determined, implying a simultaneous two-way exports and FDI pattern. The horizontal MNEs do not trade their products but produce for their local market. Hence, both exporters and MNEs serve their home market with home production.

FDI depends on factor endowments, trade costs, and fixed investment costs. We assume that three factors (low-skilled labor, $L$, high-skilled labor, $H$, and physical capital, $K$ ) are employed in the goods production. Without any loss of generality, invention of a blueprint necessitates only $H$ as an input, and plant setup requires $K$ exclusively. For simplicity, we rescale the input coefficients for blueprint invention and plant setup to one.

\subsection{Factor markets}

Let $n_{i}\left(m_{i}\right)$ denote the number of exporters (MNEs) located in country $i . x_{i i}$ is the goods production for a firm's home market, whereas $x_{i j}$ refers to a firm's exports from country $i$ to $j$ and includes iceberg trade costs similar to Markusen and Venables (2000). Then, the resource constraints are given by Eq. (1)

$$
\begin{aligned}
& L_{i}=a_{L x}\left(\mathbf{w}_{\boldsymbol{i}}\right)\left[\left(n_{i}+m_{i}+m_{j}\right) x_{i i}+n_{i} x_{i j}\right] \\
& H_{i}=a_{H x}\left(\mathbf{w}_{\boldsymbol{i}}\right)\left[\left(n_{i}+m_{i}+m_{j}\right) x_{i i}+n_{i} x_{i j}\right]+n_{i}+m_{i} \\
& K_{i}=a_{K x}\left(\mathbf{w}_{i}\right)\left[\left(n_{i}+m_{i}+m_{j}\right) x_{i i}+n_{i} x_{i j}\right]+n_{i}+(1+(1+\gamma)(1-\sigma)) m_{i} \\
& \left.K_{j}=a_{K x}\left(\mathbf{w}_{j}\right)\left[\left(n_{j}+m_{i}+m_{j}\right) x_{j j}+n_{j} x_{j i}\right]+n_{j}(1-\sigma)+(2+\gamma-\sigma)\right) m_{i}
\end{aligned}
$$

where $a_{L x}\left(\mathbf{w}_{\boldsymbol{i}}\right), a_{H x}\left(\mathbf{w}_{\boldsymbol{i}}\right)$, and $a_{K x}\left(\mathbf{w}_{\boldsymbol{i}}\right)$ are input coefficients for the production of one unit of output in country $i$, all depending on the vector of domestic factor rewards $\left(\mathbf{w}_{\boldsymbol{i}}\right)$. We assume that structural funds $(\sigma)$ simultaneously lower both pure trade costs $(t)$ and the setup costs of plants. We define trade costs as country-specific iceberg transportation costs $\left(t=t_{0}(1-\varphi \sigma)\right)$, where $\varphi$ measures the importance of structural subsidies for transport costs in relation to fixed plant setup costs. For simplicity and without any loss of generality, we only consider country $j$ as a recipient of structural subsidies. Noteworthy, this implies that the impact of structural subsidies on bilateral trade costs is symmetric (i.e., both countries' trade costs are lowered) while fixed plant setup costs are not (compare the two different capital market clearing conditions above). This implies that both country $j$ 's exporters and MNEs as well as foreign investments of MNEs headquartered in country $i$ face lower fixed plant costs in country $j$. In contrast, country $i$ 's exporters' fixed costs remain unaffected. Formally, country i's MNEs have to spend one unit of capital for their home plant (and similar country $i$ 's exporters), but only $(1+\gamma)(1-\sigma)$ units for their foreign affiliate in country $j$. Country $j$ 's 
MNEs must spend $(1-\sigma)$ units for their home plant (the same holds true for country $j$ 's exporters), but $(1+\gamma)$ for their foreign plant.

\subsection{Demand side}

A CES (Dixit \& Stiglitz, 1977) utility function yields the following demand curves (Eq. (2)):

$$
x_{i i}=p_{i i}^{-\varepsilon} s_{i}^{\varepsilon-1} E_{i} \quad: \quad x_{i j}=p_{i i}^{-\varepsilon} t_{j}^{1-\varepsilon} s_{j}^{\varepsilon-1} E_{j}
$$

with $\varepsilon$ as the elasticity of substitution, $E_{i}$ denoting domestic factor income (GNP), and $s_{i}$ as the price aggregator (Eq. (3)) (see Markusen \& Venables, 2000)

$$
s_{i}=\left[\left(n_{i}+m_{i}+m_{j}\right) p_{i i}^{1-\varepsilon}+n_{j}\left(t_{i} p_{j j}\right)^{1-\varepsilon}\right]^{1 /(1-\varepsilon)} .
$$

\subsection{Zero profit conditions}

Free entry guarantees zero profits for both exporters (superscript e) and MNEs (superscript m):

$$
\begin{aligned}
& \pi_{i}^{\mathrm{e}}=p_{i i} x_{i i}+p_{i i} x_{i j}-w_{L_{i}} x_{i i}-w_{L_{i}} x_{i j}-w_{H_{i}}-w_{K_{i}} \\
& \pi_{i}^{\mathrm{m}}=p_{i i} y_{i i}+p_{j j} y_{i j}-w_{L_{i}} y_{i i}-w_{L_{i}} y_{i j}-w_{H_{i}}-(1+(1+\gamma)(1-\sigma)) w_{K_{i}}, \\
& \pi_{j}^{\mathrm{e}}=p_{j j} x_{j j}+p_{j j} x_{j i}-w_{L_{j}} x_{j j}-w_{L_{j}} x_{j i}-w_{H_{j}}-(1-\sigma) w_{K_{j}} \\
& \pi_{i}^{\mathrm{m}}=p_{i i} y_{i i}+p_{j j} y_{i j}-w_{L_{i}} y_{i i}-w_{L_{j}} y_{i j}-w_{H_{i}}-(2+\gamma-\sigma) w_{K_{i}} .
\end{aligned}
$$

Implicitly, these two pairs of conditions (Eqs. (4) and (5)) represent the proximity-concentration trade-off for given factor rewards.

\subsection{Balance of payments}

We focus on real figures and measure country $i$ 's real exports by $n_{i} x_{i j}$. The real stock of outward FDI (foreign owned capital) includes the subsidized capital for the plant setup due to structural funds. Accordingly, country $i$ 's real FDI amounts to $m_{i}(1+\gamma)$.

The balance of payments requires that goods trade flows are balanced by both trade in invisibles and capital flows across borders, where the former are headquarter services and the latter is interpreted as FDI (Eq. (6)).

$$
n_{i} p_{i i} x_{i j}+(1-\theta) p_{j j} x_{j j} m_{i}=n_{j} p_{j j} x_{j i}+(1-\theta) p_{i i} x_{i i} m_{j} .
$$


Headquarter services and FDI enter the balance of payments as a bundle, which is equivalent to the profits of the foreign affiliates. Note $\theta$ is defined as $(E-1) / \varepsilon$.

\subsection{Simulation results}

Because of the nonlinearities induced by iceberg transportation costs, the model has to be solved numerically for particular parameter values. In the following, we consider only interior solutions (see Appendix for details on the simulations).

Fig. 1 summarizes the results of the comparative static analysis of real outward FDI with respect to changes in structural subsidies $(\sigma)$ and the parameter for the relative intensity of transport costs $(\varphi)$. The impact of $\sigma$ depends on $\varphi$. At very low values of $\varphi$, FDI increases with $\sigma$ and substitutes country $i$ 's real exports. At medium values of $\varphi$, the resulting FDI locus is concave with a complementary effect on exports at low values of $\sigma$ and a substitutive one if $\sigma$ gets high. Finally, very high values of $\varphi$ imply that the transport cost reduction induced by higher $\sigma$ is large enough in order to change the proximity-concentration trade-off in favor of exports leading to a reduction of real FDI from $i$ to $j$. The impact of the structural funds is thus an empirical matter.

Concerning the remaining determinants, we find the following comparative static results. FDI is a positive function of relative GDP $\left(G_{i j}=G D F_{i} / G D F_{j}\right)$. An increase in the relative physical capital-to-labor ratio $\left(k_{i j}=\left(K_{i} / L_{i}\right) /\left(K_{j} / L_{j}\right)\right)$ exerts a positive impact on real FDI from country $i$ to $j$ due to the abundance of physical capital. The same holds true for an increase in the relative human capital-to-labor ratio $\left(h_{i j}=\left(H_{i} / L_{i}\right) /\left(H_{j} / L_{j}\right)\right)$, resulting from the increasing comparative advantage in the invention of blueprints, the consumers' taste for variety, and the MNE's opportunity to jump trade costs. Finally, pure trade costs $(t)$ exhibit a negative effect on FDI since they change the proximityconcentration trade-off in favor of multinational activity.

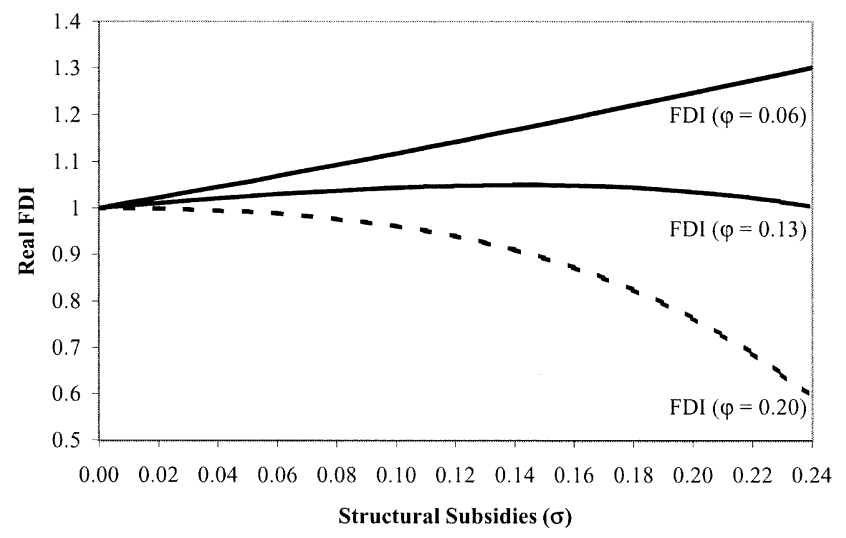

Fig. 1. Structural subsidies and their impact on FDI. 


\section{The empirical FDI gravity model and data sources}

According to the theoretical background we can formulate the following dynamic gravity model, which accounts for the impact of structural subsidies on bilateral outward FDI:

$$
\begin{aligned}
\Delta F_{i j t}= & \beta_{o}+\beta_{1} \Delta F_{i j(t-1)}+\beta_{2} \Delta F_{i j(t-2)}+\beta_{3} \Delta \sigma_{i j(t-1)}+\beta_{4} \Delta G_{i j(t-1)} \\
& +\beta_{5} \Delta G_{i j(t-2)}+\beta_{6} \Delta k_{i j(t-1)}+\beta_{7} \Delta k_{i j(t-2)}+\beta_{8} \Delta h_{i j(t-1)} \\
& +\beta_{9} \Delta h_{i j(t-2)}+\beta_{10} \Delta t_{i j(t-2)}+\beta_{11} \Delta V_{j(t-1)}+\beta_{12} \Delta V_{i(t-1)} \\
& +\beta_{13} \Delta R_{j(t-1)}+\beta_{14} \Delta R_{j(t-1)}+\lambda_{t}+u_{i j t}
\end{aligned}
$$

where all variables are in $\log$ differences (indicated by $\Delta$ ). We measure transport costs by the difference between bilateral trade figures in c.i.f. and f.o.b. (compare Baier \& Bergstrand, 2001). Other aspects of impediments to trade and/or FDI are measured by exporter and importer viability of contracts $\left(V_{i}, V_{j}\right)$ and rule of law $\left(R_{i}, R_{j}\right) . \lambda_{t}$ are fixed time effects in order to control for common cycle influences.

Table 1 provides information on the data sources. We consider the reported book values of foreign assets as a rough approximation of depreciated initial values of outward stocks of FDI and convert them to real figures by the use of investment deflators (OECD National Accounts, Volume 1) in combination with the exchange rate indices for all countries, in order to arrive at a proxy for real stocks of bilateral FDI using 1995 as the base year. Real values of structural expenditures and GDP are obtained by using GDP deflators. We measure $h_{i j}$ by the relation of at least

Table 1

Data sources

\begin{tabular}{ll}
\hline Variable & Source \\
\hline $\begin{array}{l}\text { Outward stocks of FDI } \\
\text { Investment deflators }\end{array}$ & OECD, International Direct Investment Statistics Yearbook \\
Structural funds & OECD National Accounts, Volume 1 \\
Exports and imports & EU \\
& OECD, Monthly Statistics of International Trade; IMF, Direction \\
of Foreign Trade; and the Vienna Institute of International & Economic Studies \\
Export and import prices & IMF, International Financial Statistics; OECD, Economic Outlook; \\
& and the Vienna Institute of International Economic Studies \\
OECD, Economic Outlook and National Accounts Volume 1; IMF, & International Financial Statistics; and the Vienna Institute \\
of International Economic Studies & $\begin{array}{l}\text { OECD Education Statistics 1985-1992, Education at a Glance, } \\
\text { School enrolment }\end{array}$ \\
several years, and the UNESCO Statistical Yearbook \\
OECD, Economic Outlook and National Accounts Volume 1; IMF, \\
capital formation & $\begin{array}{l}\text { International Financial Statistics; and the Vienna Institute } \\
\text { of International Economic Studies }\end{array}$ \\
Viability of contracts & Economic Freedom Network (Economic Freedom of the World) \\
Rule of law & Economic Freedom Network (Economic Freedom of the World) \\
\hline
\end{tabular}


secondary to primary enrolment figures. Real capital stocks are estimated by the perpetual inventory method. We set the initial period's (1978) capital stock at

$$
K_{1978}=2\left(I_{1976}+I_{1977}+I_{1978}+I_{1979}+I_{1980}\right)
$$

where $I_{t}$ is the gross fixed capital formation (Eq. (8)). Additionally, we assume a constant and identical depreciation rate of $7 \%$. Then, the real capital stocks in the other years are (Eq. (9))

$$
K_{t}=0.93 \cdot K_{t-1}+I_{t}
$$

$k_{i}$ is the ratio between the real stock of capital and low-skilled labor, which is measured by employment times the share of primary school enrolment. The panel covers the period 1986 to 1997 of FDI in the EU and is unbalanced, mainly due to the availability of bilateral data on FDI stocks. After removing all bilateral relations with less than 6 observations, we come up with 574 observations in the regression analysis.

\section{Estimation results}

We estimate Eq. (7) by GMM using the Arellano and Bond (1991) estimator in order to overcome the Nickell (1981) bias, which is important since our time series are short. Only the lagged dependent variables are treated as endogenous and instrumented according to Arellano and Bond (1991) using lags of order three or higher. Table 2 presents the estimation results for three specifications. Specifications $\mathrm{AB}(1)$ and $\mathrm{AB}(2)$ are restricted forms of $\mathrm{AB}(3)$, and all three provide comparable and very robust results. The test for second order correlation reveals that the appropriateness of the GMM procedure is not rejected. Except for specification $\mathrm{AB}(1)$, the Sargan (1958) overidentification test statistics indicate that the appropriateness of the instrument choice is not rejected (see Baltagi, 1995). In all specifications, time effects exhibit a significant impact.

In any case, we find a significant positive short run impact of a change in structural expenditures on a change in outward stocks of FDI, which amounts to an elasticity of about 0.13 in the preferred model, $\mathrm{AB}(3)$. Except for changes in the human capital-to-labor ratio $\left(h_{i j}\right)$, the sign of the estimated parameters is in accordance with our theoretical hypotheses.

The reported parameters reflect only short-run influences. Table 3 reports the implied long-run effects of changes in the exogenous variables. ${ }^{2}$ The long-run

2 The long-run effect of an exogenous variable with parameter $\beta_{j}$ is calculated as $\beta_{j} /\left(1-\beta_{1}-\beta_{2}\right)$. The matrix of the corresponding standard deviations is given by (see Bårdsen, 1989):

$$
\widehat{V(K)}=J \bar{V} J^{\prime}
$$

where $J=(\partial K) /(\partial \beta)$ and $K$ is the vector of long-run multipliers. 
Table 2

Panel regression results for bilateral stocks of outward FDI (only first differences of real figures and variables in logs)

\begin{tabular}{|c|c|c|c|c|}
\hline Independent variables & Label & $\mathrm{AB}(1)$ & $\mathrm{AB}(2)$ & $\mathrm{AB}(3)$ \\
\hline Lagged real stocks of outward FDI & $F_{i j,(t-1)}$ & $0.380 * * *(0.016)$ & $0.330 * * *(0.018)$ & $0.307 * * *(0.021)$ \\
\hline Twice lagged real stocks of outward FDI & $F_{i j,(t-2)}$ & $0.205 * * *(0.010)$ & $0.179 * * *(0.011)$ & $0.169 * * *(0.012)$ \\
\hline Lagged structural funds & $\delta_{i j,(t-1)}$ & $0.164 * * *(0.021)$ & $0.135 * * *(0.019)$ & $0.134 * * *(0.019)$ \\
\hline Lagged relative bilateral GDP & $G_{i j,(t-1)}$ & $0.662 * * *(0.200)$ & $0.867 * * *(0.234)$ & $0.804 * * *(0.234)$ \\
\hline Twice lagged relative bilateral GDP & $G_{i j,(t-2)}$ & $0.606 * *(0.234)$ & $0.804 * * *(0.243)$ & $0.693 * *(0.277)$ \\
\hline Lagged relative physical capital-to-unskilled labor ratio & $k_{i j,(t-1)}$ & $0.630 * * *(0.098)$ & $0.590 * * *(0.110)$ & $0.660 * * *(0.113)$ \\
\hline $\begin{array}{l}\text { Twice lagged relative physical capital-to-unskilled } \\
\text { labor ratio }\end{array}$ & $k_{i j,(t-2)}$ & $-0.138(0.103)$ & $-0.158(0.106)$ & $-0.215^{* *}(0.110)$ \\
\hline Lagged relative human capital-to-unskilled labor ratio & $h_{i j,(t-1)}$ & $-0.751 * * *(0.100)$ & $-0.732 * * *(0.109)$ & $-0.794 * * *(0.110)$ \\
\hline $\begin{array}{l}\text { Twice lagged relative human capital-to-unskilled } \\
\text { labor ratio }\end{array}$ & $h_{i j,(t-2)}$ & $0.013(0.109)$ & $0.022(0.108)$ & $0.110(0.102)$ \\
\hline Twice lagged transport costs & $t_{i j,(t-2)}$ & $0.220 * * *(0.030)$ & $0.229 * * *(0.031)$ & $0.286 * * *(0.031)$ \\
\hline Lagged importer viability of contracts & $V_{j,(t-1)}$ & & $1.532 * * *(0.198)$ & $1.608 * * *(0.208)$ \\
\hline Lagged exporter viability of contracts & $V_{j,(t-1)}$ & & $0.214(0.153)$ & $0.044(0.165)$ \\
\hline Lagged importer rule of law & $R_{j,(t-1)}$ & & & $-0.204(0.168)$ \\
\hline Lagged exporter rule of law & $R_{t,(t-1)}$ & & & $0.383 * * *(0.120)$ \\
\hline Constant & $\beta_{0}$ & $0.060 * * *(0.006)$ & $0.058 * * *(0.007)$ & $0.055 * * *(0.008)$ \\
\hline Number of observations & & 574 & 574 & 574 \\
\hline$R^{2}$ & & .19 & .18 & .18 \\
\hline Time effects: $\chi^{2}(8)$ & & $920.84 * * * 0.00$ & $468.33 * * * 0.00$ & $465.01 * * *(0.00)$ \\
\hline First order autocorrelation & & $-1.69 *(0.09)$ & $-1.67 *(0.09)$ & $-1.68 *(0.09)$ \\
\hline Second order autocorrelation & & $-0.96(0.34)$ & $-0.85(0.40)$ & $-0.8(0.42)$ \\
\hline Sargan test: $\chi^{2}(52)$ & & $67.69 *(0.07)$ & $61.43(0.17)$ & $61.80(0.17)$ \\
\hline
\end{tabular}

Standard errors in parentheses.

* Significant at $10 \%$

** Significant at $5 \%$.

*** Significant at $1 \%$. 
Table 3

Long-run parameters and standard errors for bilateral stocks of outward FDI

\begin{tabular}{|c|c|c|c|c|}
\hline Independent variables & Label & $\mathrm{AB}(1)$ & $\mathrm{AB}(2)$ & $\mathrm{AB}(3)$ \\
\hline Structural funds & $\delta_{i j}$ & $0.394 * * *(0.058)$ & $0.275 * * *(0.043)$ & $0.255 * * *(0.042)$ \\
\hline Relative bilateral GDP & $G_{i j}$ & $3.058 * * *(0.483)$ & $3.409 * * *(0.413)$ & $2.854 * * *(0.450)$ \\
\hline $\begin{array}{l}\text { Relative physical } \\
\text { capital-to-unskilled } \\
\text { labor ratio }\end{array}$ & $k_{i j}$ & $1.187 * * *(0.201)$ & $0.881 * * *(0.215)$ & $0.848 * *(0.228)$ \\
\hline $\begin{array}{l}\text { Relative human } \\
\text { capital-to-unskilled } \\
\text { labor ratio }\end{array}$ & $h_{i j}$ & $-1.778 * * *(0.218)$ & $-1.450 * * *(0.188)$ & $-1.302 * * *(0.169)$ \\
\hline Transport costs & $t_{i j}$ & $0.530 * * *(0.083)$ & $0.467 * * *(0.070)$ & $0.545^{* * *}(0.071)$ \\
\hline $\begin{array}{l}\text { Importer viability } \\
\text { of contracts }\end{array}$ & $V_{j}$ & - & $3.126 * * *(0.409)$ & $3.065^{* * *}(0.420)$ \\
\hline $\begin{array}{l}\text { Exporter viability } \\
\text { of contracts }\end{array}$ & $V_{i}$ & - & $0.436(0.318)$ & $0.083(0.316)$ \\
\hline Importer rule of law & $R_{j}$ & - & - & $-0.389(0.315)$ \\
\hline Exporter rule of law & $R_{i}$ & - & - & $0.731^{* *}(0.222)$ \\
\hline Constant & $\beta_{0}$ & $0.144 * * *(0.013)$ & $0.118 * * *(0.013)$ & $0.105 * * *(0.014)$ \\
\hline Long-run multiplier & & 2.411 & 2.040 & 1.906 \\
\hline
\end{tabular}

Standard errors in parentheses.

** Significant at $5 \%$.

$* * *$ Significant at $1 \%$.

effect of a shock in structural funds corresponds to the double amount of about 0.26 in the preferred model. The underlying speed of adjustment is considerably high and implies that half of the adjustment to the equilibrium is accomplished within 2 years after the shock in $\sigma .^{3}$

Using the results in Tables 2 and 3 and the preferred model $\mathrm{AB}(3)$, we are able to simulate the impact of the structural policy reform on the real stocks of outward FDI in the EU countries (Table 4). We consider the effect of a change in structural expenditures as suggested by Agenda 2000 and investigate the long-run effects under the assumption that change has occurred within the estimation period (1986-1997), all else being equal. ${ }^{4}$ In real terms, the resulting shock is smallest in absolute terms for Germany in both the short-run and the long-run perspective. The most favored country is Greece where - in the long-run - the expected change in the bilateral stock of outward FDI from the average country amounts to $0.76 \%$. In contrast, Ireland faces the most massive reduction of $15.85 \%$ of the outward FDI stock. Besides Ireland, a couple of other countries (Belgium-Luxembourg, Denmark, Austria, and the UK) suffer pronounced losses as well, facing reductions in outward FDI stocks

\footnotetext{
${ }^{3}$ However, this speed of adjustment is not identical across variables, since some of them enter the specification twice and with different lags.

${ }^{4}$ We assume that the relationship between actual and budgeted expenditures on structural operations remains constant.
} 
Table 4

Assessing the impact of a reduction in structural funds on real outward stocks of FDI in the EU: parameters from model $\mathrm{AB}(3)$

\begin{tabular}{lccccc}
\hline & \multicolumn{2}{c}{$\begin{array}{l}\text { Average annual level of structural } \\
\text { funds in US dollars }\end{array}$} & & \multicolumn{2}{c}{$\begin{array}{l}\text { Percentage change of inward } \\
\text { stocks of FDI }\end{array}$} \\
\cline { 2 - 3 } \cline { 5 - 6 } EU country & $1995 / 1999$ & & & Short-run & Long-run \\
\hline Belgium-Luxembourg & 518.3 & 372.0 & & -3.77 & -7.19 \\
Denmark & 190.0 & 134.9 & & -3.88 & -7.39 \\
Germany & 5178.6 & 5244.9 & & 0.17 & 0.33 \\
Greece & 3782.6 & 3895.4 & & 0.40 & 0.76 \\
Spain & 9358.9 & 9029.9 & & -0.47 & -0.90 \\
France & 3437.0 & 2662.7 & & -3.01 & -5.74 \\
Ireland & 1552.5 & 586.2 & & -8.31 & -15.85 \\
Italy & 4409.1 & 4214.9 & & -0.59 & -1.12 \\
Netherlands & 618.6 & 569.0 & -1.07 & -2.04 \\
Austria & 446.5 & 321.9 & -3.73 & -7.10 \\
Portugal & 3971.6 & 3605.9 & -1.23 & -2.34 \\
Finland & 466.4 & 361.0 & -3.02 & -5.76 \\
Sweden & 357.7 & 331.2 & -0.99 & -1.89 \\
United Kingdom & 2574.7 & 1912.1 & -3.44 & -6.55 \\
\hline
\end{tabular}

from abroad of around 7\%. This underpins the importance of compensating measures in order to mitigate the possible detrimental effects from Agenda 2000's structural policy reform.

\section{Conclusions}

This paper analyses the effects of the EU Structural Policy Reform due to the Berlin European Council on FDI stocks in the EU. The theoretical hypotheses are based on a three-factors model of trade and FDI, where the expected impact of structural expenditures depends on whether structural policy mainly is trade cost reducing or directly reducing fixed investment costs. We estimate a dynamic gravity panel data model for bilateral outward FDI stocks from OECD countries in the EU and find a pronounced and robust positive impact of a change in structural expenditures on bilateral FDI. Distinguishing between short-run and long-run effects, we use the estimation results for an experiment of thought. Assuming that the policy reform would have taken place within the estimation period (1986-1997) holding other influences constant, we find that the resulting long-run reduction in real FDI stocks is highest in Ireland, amounting to about $15.9 \%$. Also other countries such as Belgium-Luxembourg, Denmark, Austria, and the UK are affected by considerable reductions of about $7 \%$. Hence, the distributional impact of the change in the structural policy induced by Agenda 2000 goes beyond the direct figures agreed upon. Given the estimated size of the reduction in FDI in the current EU member countries, compensating measures should be taken 
into account in order to mitigate the possible detrimental effects from Agenda 2000's structural policy reform. A good opportunity to consider such compensating measures could be the negotiations for the next EU budget in 2005 for the financial period 2007-2013. At that time, the EU will probably be already enlarged by the majority of the present 12 candidate countries.

\section{Acknowledgments}

We would like to thank G. Tondl and H. Badinger for helpful suggestions.

\section{Appendix. Simulation details}

We derive input coefficients from a Cobb Douglas production technology (Eq. (10)):

$$
\begin{aligned}
& a_{L_{x i}}=\left(\frac{w_{H_{i}}}{w_{L_{i}}} \frac{a}{b}\right)^{b}\left(\frac{w_{K_{i}}}{w_{L_{i}}} \frac{a}{c}\right)^{c} \\
& a_{H_{x i}}=\left(\frac{w_{L_{i}}}{w_{H_{i}}} \frac{b}{a}\right)^{a}\left(\frac{w_{K_{i}}}{w_{H_{i}}} \frac{b}{c}\right)^{c} \\
& a_{K_{x i}}=\left(\frac{w_{L_{i}}}{w_{K_{i}}} \frac{c}{a}\right)^{a}\left(\frac{w_{H_{i}}}{w_{K_{i}}} \frac{c}{b}\right)^{b}
\end{aligned}
$$

and similarly for country $j$ assuming constant returns to scale $(a+b+c=1)$ and identical technology parameters across countries of $a=0.6, b=0.2$, and $c=0.2$. We label unit costs by (Eq. (11))

$$
\begin{aligned}
& d_{i}=a_{L_{x i}} w_{L_{i}}+a_{H_{x i}} w_{H_{i}}+a_{K_{x i}} w_{K_{i}} \\
& d_{j}=a_{L_{x j}} w_{L j}+a_{H_{x j}} w_{H j}+a_{K_{x j}} w_{K_{j}} .
\end{aligned}
$$

We choose $w_{L_{j}}=1$ and simulate the following 11 conditions in order to obtain results for the remaining 11 variables (Eq. (12): $w_{L_{i}}, w_{K_{i}}, w_{K_{j}}, w_{H_{i}}, w_{H_{i}}, x_{i i}, x_{j j}, n_{i}$, $n_{j}, m_{i}, m_{j}$ :

$$
\begin{aligned}
& \frac{L_{i}}{a_{L_{x i}}}-\left(n_{i}+m_{i}+m_{j}\right) x_{i i}-n_{i} x_{j j} t^{1 \cdot \varepsilon}\left(\frac{d_{i}}{d_{j}}\right)^{-\varepsilon}=0 \\
& \frac{L_{j}}{a_{L_{x j}}}-\left(n_{j}+m_{i}+m_{j}\right) x_{j j}-n_{j} x_{i i} t^{1 \cdot \varepsilon}\left(\frac{d_{i}}{d_{j}}\right)^{\varepsilon}=0
\end{aligned}
$$




$$
\begin{aligned}
& H_{i}-\frac{a_{H_{x i}} L_{i}}{a_{L_{x i}}}-n_{i}-m_{i}=0 \\
& H_{j}-\frac{a_{H_{x j}} L_{j}}{a_{L_{x j}}}-n_{j}-m_{j}=0 \\
& K_{i}-\frac{a_{K_{x i}} L_{i}}{a_{L_{x i}}}-n_{i}-(1+(1+\gamma)(1-\sigma)) m_{i}=0 \\
& K_{j}-\frac{a_{K_{x j}} L_{j}}{a_{L_{x j}}}-n_{j}((1-\sigma)-(2+\gamma-\sigma)) m_{i}=0 \\
& x_{i i}+x_{j j} t^{1-\varepsilon}\left(\frac{d_{i}}{d_{j}}\right)^{-\varepsilon}-\frac{(\varepsilon-1)\left(w_{H_{i}}+w_{K_{i}}\right)}{d_{i}}=0 \\
& x_{j j}+x_{i i} t^{1-\varepsilon}\left(\frac{d_{i}}{d_{j}}\right)^{\varepsilon}-\frac{(\varepsilon-1)\left(w_{H j}+(1-\sigma) w_{K j}\right)}{d_{i}}=0 \\
& x_{j j}+x_{i i}\left(\frac{d_{i}}{d_{j}}\right)-\frac{(\varepsilon-1)\left(w_{H j}+(2+\gamma-\sigma) w_{K j}\right)}{d_{j}}=0 \\
& x_{i i}+x_{j j}\left(\frac{d_{j}}{d_{i}}\right)-\frac{(\varepsilon-1)\left(w_{H_{i}}+(1+(1+\gamma)(1-\sigma)) w_{K_{i}}\right)}{d_{j}}=0 \\
& \left.n_{i}\left(\frac{d_{i}}{d_{j}}\right)^{1-\varepsilon} n_{j}\left(\frac{d_{i}}{d_{j}}\right)^{\varepsilon}+\frac{m_{j}}{\varepsilon} \frac{d_{i}}{d_{j}}\right)=0 .
\end{aligned}
$$

For our simulations, we set the world endowments (labeled by a " $\sim$ ") at $\tilde{L}=100, \tilde{H}=120$, and $\tilde{K}=250$. Furthermore, we assume $t_{0}=1.5, \gamma=0.5, \varepsilon=2$, $0 \leq \sigma \leq 0.24$, and $0.1 \leq \varphi \leq 1.3$.

\section{References}

Arellano, M., \& Bond, S. (1991). Some tests of specification for panel data: Monte Carlo evidence and an application to employment equations. Review of Economic Studies, 58, $277-297$.

Baier, S. L., \& Bergstrand, J. H. (2001). The growth of world trade: tariffs, transport costs, and income similarity. Journal of International Economics, 53, 1-27.

Baltagi, B. H. (1995). Econometric analysis of panel data. Chichester: Wiley.

Bårdsen, G. (1989). Estimation of long run coefficients in error correction models. Oxford Bulletin of Economics and Statistics, 50, 345-500. 
Bergstrand, J. H. (1989). The generalized gravity equation, monopolistic competition, and the factorproportions theory in international trade. Review of Economics and Statistics, 71, 143-153.

Bergstrand, J. H. (1990). The Heckscher-Ohlin-Samuelson model, the Linder hypothesis and the determinants of bilateral intra-industry trade. Economic Journal, 100, 1216-1229.

Dixit, A., \& Stiglitz, J. E. (1977). Monopolistic competition and optimum product diversity. American Economic Review, 67, 297-308.

Helpman, E. (1987). Imperfect competition and international trade: evidence from fourteen industrial countries. Journal of the Japanese and International Economies, 1, 62-81.

Helpman, E., \& Krugman, P. R. (1985). Market structure and foreign trade. Cambridge, MA: MIT Press.

Markusen, J. R., \& Venables, A. J. (1998). Multinational firms and the new trade theory. Journal of International Economics, 46, 183-203.

Markusen, J. R., \& Venables, A. J. (2000). The theory of endowment, intra-industry, and multinational trade. Journal of International Economics, 52, 209-234.

Nickell, S. J. (1981). Biases in dynamic models with fixed effects. Econometrica, 49, 1417-1426.

Sargan, D. J. (1958). The estimation of economic relationships using instrumental variables. Econometrica, 26, 393-415.

Wang, Z. K., \& Winters, A. L. (1991). The trading potential of Eastern Europe. CEPR Discussion Paper No. 610. 